\title{
Human Rights and Social Work: Beyond Conservative Law
}

\author{
$\operatorname{Jim}$ Ife $^{1}$
}

Published online: 3 March 2016

(C) Springer International Publishing 2016

\begin{abstract}
We can think about social work and human rights in two ways: social workers joining broader human rights campaigns, and achieving human rights through social work practice. This paper concentrates on the latter approach, identifying the limitations of conventional legal-based human rights narratives for social work. By extending the idea of human rights to concentrate on the 'human', and by recognising the limitations of individualist liberal constructions of human rights, this paper argues for human rights based social work grounded in the humanities. It also identifies some important future challenges for human rights based social work within a less anthropocentric world view.
\end{abstract}

Keywords Human rights · Social work practice $\cdot$ Law . Humanities · Humanity $\cdot$ Enlightenment $\cdot$ Modernity · Anthropocentrism

Social work's relationship with human rights has been understood in two ways. One has been about social work's involvement with various human rights campaigns and supporting human rights initiatives, through national, regional and global social work bodies, and through social workers' role as activists. Thus social workers have been strong supporters of Amnesty International, have made submissions to UN bodies in relation to human rights issues, and have participated

This paper includes part of an otherwise unpublished keynote presentation to a conference on Human Rights and Equality from Below at Maynooth University, Ireland in September 2015

Jim Ife

jimife@iinet.net.au

1 Centre for Human Rights Education, Curtin University, Perth, Australia actively in various human rights campaigns, consistent with the values of social work.

In the Australian context, social workers have been active in campaigns around key human rights issues, one of the most important being the continuing disadvantage suffered by Indigenous People in Australia. In this regard, the role of welfare services in the forced removal of Aboriginal children from their families, up to the 1970s, is a major case of human rights abuse, which has had profound implications for generations of Indigenous People. This is an indictment of earlier generations of social workers who participated in these forced removals, and it is significant that the Australian Association of Social Workers has publicly apologised for the role social workers have played in such human rights abuse in the past. The profession has moved to address this in three ways: first by requiring significant content on Indigenous cultures and cross-cultural practice in all social work education programmes, second by seeking to validate Indigenous voices and to support Indigenous knowledge and world views as essential for social workers, and third by supporting and working in solidarity with Indigenous struggles for social justice and human rights. There is still a long way to go in achieving this goal, but social workers, in many cases led by Indigenous social workers, are now actively seeking to be part of the solution rather than part of the problem.

Australia's treatment of asylum seekers, in the last 15 years, has been the subject of major criticism, both within Australia and internationally. Many Australian social workers have been active in the movement for asylum seeker rights, whether as activists, advocates or service providers, and have also been part of many community-based initiatives to challenge oppressive government policy, to welcome asylum seekers into the Australian community, and to provide them with necessary ed support services.

Australian social workers have also been part of the struggle for human rights in other areas: domestic violence, child protection, disability rights, age discrimination, women's 
rights, mental health rights, LGBTIQ rights, and so on. Australia faces a wide range of human rights issues, and social workers have been active across them all.

But, as indicated above, such involvement in, and support of, human rights activism is only one way in which we can think about social work and human rights. The other way is to consider the idea of human rights as a basis for social work practice, and to think of social workers as human rights workers in their daily professional work. That is the primary concern of this paper, which is a reflection on the problematic relationship between human rights and social work, a relationship that raises significant challenges for social workers who wish to incorporate human rights perspectives into social work practice. This is a result of the problematic and contradictory nature of human rights. Human rights is a difficult concept in that it is at the same time progressive and also conservative. The progressive potential of human rights has been significant in informing social work, but at the same time the conservative attributes of human rights can limit and restrict social work from its transformative potential.

\section{Human Rights as Progressive}

The modern discourse of human rights can be said to derive from the European Enlightenment (Hunt 2007), and the ideals of the French and American revolutions in the late 18th century, though of course many of the ideas and values are much older. Human rights then achieved a new impetus following World War 2 (especially the Holocaust), with the establishment of the United Nations, the Universal Declaration in 1948, and the founding of Amnesty International in 1961. It is thus firmly identified with internationalist movements for a better and fairer world. However human rights developed an additional impetus after 1989; with the decline of socialism, human rights became, in the western world, almost the only legitimate location for opposition to the established order, and for many activists it took on a more radical perspective. Many critics used the ideas and language of human rights to argue for social justice and a fairer world. The anti-globalisation demonstrators of the 1990s used the language of human rights, as did anti-colonialist writers, the Madres (Mothers of the disappeared) in Argentina (Tascón 2015), and so on. To quote the Argentine political film-maker Julio Santucho, 'In the nineties, human rights occupy the place of the socialism of the seventies: they call forth the subversives' (Tascón 2015 p. 137). This gave human rights a more radical image, and enabled many people to be 'safely' radical; human rights, after all, was a respectable idea, supported by the United Nations and by Bills of Rights in various countries. This suited progressive social work well and there is no doubt that social work's association with human rights has had positive results for social work and for those vulnerable populations that social work represents. It should be noted, however, that there are now other legitimate discourses of opposition, and radicals no longer need the human rights movement to give them legitimacy. Since the Global Financial Crisis in 2008, socialist ideas have regained a level of popularity and legitimacy, and people can write about Marx again without apologising (e.g. Harvey 2014). Perhaps even more important, the urgency of the ecological crises facing humanity, and the growing strength of the various strands of the environment movement, provide a strong challenge to the existing social economic and political order, and are attracting increasing numbers of activists (e.g. Klein 2014). Human rights no longer occupies the central location in progressive politics that it did in the 1990s. These trends are paralleled in social work; human rights has been a central idea for progressive social work since the 1990 s, but progressive social workers now also have other narratives of analysis and action.

This does not mean that human rights cease to be important. The very idea of human rights is central to formulating an approach to social work that is, at heart, progressive. It challenges the more conservative arguments for services based on ideas of 'deserving', and on ideas of 'need'. These ideas are strong in mainstream political discourse in the era of neoliberalism, and in this context to claim that people are entitled to a service, benefit or resource not because they deserve it, or even because they need it, but because they have a right to it on the basis simply of their humanity, is truly radical. This is not new in social work - it resonates throughout the history of the profession - but in the current context the powerful narrative of human rights has strengthened social work's commitment to the central values of humanity.

\section{The Legal Story: Limiting Human Rights}

The appeal of human rights to social workers has been strong, and the importance of a human rights perspective for social work practice is clear. By seeing themselves as human rights workers, rather than as therapists, clinicians or case managers, social workers can envisage their work in a very different way, with the potential for more progressive and transformative practice. But there is another side to human rights - the conservative side - that needs to be understood, and which requires a more extended discussion. This requires social workers not just to accept a human rights perspective uncritically, but rather to engage with the difficult challenges of human rights, and to reformulate the idea of human rights so that it is more consistent with progressive social work practice. In doing so, social work can actually make a contribution to the human rights field, currently so dominated by the legal profession.

In an empirical sense, there is surely no such thing as "natural' rights. We are not, biologically, born with rights. Rather, 
rights are ascribed to us as a result of the different stories we tell ourselves about humanity and what it means to be human. The idea of human rights is powerful and important, but this does not mean that rights are natural, inevitable or self-evident. Human rights are part of the stories we tell about ourselves, and we tell different stories of human rights. One such story is the creationist one that, as the USA Founding Fathers declared, we are endowed by our Creator with inalienable rights. This only makes sense if we believe the stories of the creator and this particular version of the creation of the human. In a society where everybody, or nearly everybody, believed this story, such a way of thinking about rights made good sense. But in a society where many do not believe this story, such a view of rights loses both power and legitimacy.

Another story of rights is the legal one: rather than the creator, it is the rule of law that gives ideas of rights both strength and substance. Indeed, the law becomes the alternative 'creator' of human rights, and hence the definer of our humanity. So strongly do we believe in the rule of law, and the apparent necessity for the rule of law if human civilisation is to exist, that we forget that the law too is a story, a useful story that we have constructed to make sense of our living together in one society, but still a story. The law, and legal structures and processes, are human constructions, and in the form we know them they are a function of modern western societiesvery different from ideas of 'the law' in other cultures and at other times. They are powerful only because the vast majority of the population more or less believes in this story-indeed the idea of large numbers not accepting, but revolting against, the rule of law is too frightening for many people to contemplate - and this is a product of this historical moment. It is therefore relatively easy for us to define what it means to be human in terms of this story of the rule of law, and hence human rights become defined by, and identified with, law.

This of course was partly a reaction to the limitations of a creationist account. The European Enlightenment - the origin of modern ideas of human rights (Hunt 2007) — was a reaction against the religious wars of the 16th and 17th centuries, where many people had fought and died in conflict about who had the correct view of divine revelation. The Enlightenment sought instead to reason morality through philosophy, rather than through our interpretations of scripture or through revealed divine wisdom. This, together with the Enlightenment love of order, regulation and classification, led naturally to the codification of humanity, and hence of human rights, through the law.

But let us stop and consider the consequences of this particular story of humanity and of human rights. The idea of human rights as law has been important, and has achieved significant outcomes. The world is undoubtedly a better place because of human rights laws, human rights instruments, human rights lawyers and the human rights movement. But while celebrating the important things that the legal story of human rights has achieved, it is important also for us to remember what it does not do, or at least what it does not do very well. Because this view of human rights as law, in my view, limits the potential of human rights. This is at least in part because of the liberalism inherent in modern western views of the law. In this context, I am using the term 'liberalism' in its traditional philosophical sense, namely as an ideology that values individual freedom and liberty, rather than the common North American usage where the term loosely corresponds to social democratic values.

The first of these limitations to note is that the law is largely concerned with individuals. It is individuals who must obey the law, and individuals who have rights; in the neo-liberal age of individualism this becomes almost self-evident. Yet individualism is another story. It is just one side of our humanity, and not necessarily the most important. From an alternative story, we achieve our humanity not in splendid individual isolation, but in relationship. Indeed, in understanding reality it is important to understand that reality is made up of relationships (Spretnak 2011). The atom is only an atom because of the relationship of its fundamental particles rather than because of their individual properties, and the same thinking applies to molecules, cells, humans, families, communities and nations: they only make sense because of relationships. It is relationships that define reality, and this runs counter to the classic Enlightenment story of splitting things up into their component parts in order to study them, defining reality in terms of its constituent parts. This idea of relational reality is completely natural for Indigenous People, and indeed for almost anyone from a non-western cultural tradition, but for westerners it needs to be argued and emphasised, such is the power of the dominant individualist story. And the result of this is that ideas of humanity, and of human rights, are attached to isolated autonomous humans, rather than to people in relationship. Human rights, and therefore our humanity, belong almost exclusively to individuals, if we accept the dominant legal world view. The exception, of course, is corporations, which increasingly are defined as legal entities and hence are given rights, but other human collectivities (families, communities, gangs, religious congregations, etc.) are largely absent from this view of human rights, even though they are so important in defining our humanity. To see human rights as residing almost exclusively with individuals significantly limits the idea, especially from the relationship-based perspective of social work.

The other problem with the legal story of human rights is that in a liberal individualist society the law tends inevitably to be concerned with negative sanctions. The liberal obsession with something called 'freedom' (itself a story, of course) as the primary value of human existence means that under the law we are free to do what we want to, unless the law specifically tells us otherwise; we do not readily accept legal restrictions on our so-called 'freedom', but we recognise that, in a 
Hobbesian world of conflict, we cannot simply do as we like without some constraint, and so we accept that we need laws to tell us what we are not allowed to do. The problem with this story is that it means the law is negative-it tells us what we must not do, but does not tell us what we should do. That is left to the much weaker and more contested realm of ethics and morality, rather than law, and there is no doubt that, at least in the West, the sacrosanct 'rule of law' is seen as more significant than weaker stories of ethics and morality. Hence with a legal approach to human rights we have a rights regime that is negative - it focuses on the prevention or punishment of human rights violations, rather than what needs to be done to help people realise their rights, and through that to achieve their full humanity. As a consequence of this liberal individualist view of freedom, we can be said to have a 'right' to do anything we want to that is not actually illegal. This is a strange view of human rights; the Australian AttorneyGeneral famously and seriously said that people have a right to be a bigot if they want to; this is the consequence of a negative, legal approach to human rights in a liberal society; we can tolerate and even value people's right to be bigoted as long as they do not break any laws. Our human rights therefore become rights to do anything that is not illegal, and this is a fairly useless construction of human rights, which therefore become a series of laws of the 'thou shalt not' variety.

The legal story of human rights, therefore, has some serious limitations. Social work has often seen its role as to adopt and work within that legal model — simply accepting legal human rights instruments and seeking to apply them through social work practice. Although this is undoubtedly worthwhile, it is, in my view, only a part of what a human rights based social work should be doing.

\section{A Different Story: Bringing the Human Back into Human Rights}

It is important for social work to question the validity of the legal story as the dominant, and indeed only, legitimate approach to human rights, and to seek to tell a different story. This story can be based on relationship, on human rights as collective, and as social. This, after all, is the world that social workers inhabit, understand, and practise in.

A way to start telling this story is to think about the human part of 'human rights'. Instead of concentrating on the problematic nature of 'rights', we need instead to consider the problematic nature of 'human'. What is the nature of the 'human' that has, or claims, the rights? The idea of what counts as human has historically been, and continues to be, contested. At different times, women, children, slaves, prisoners, people with disabilities, and ethnic/racial/religious/cultural minorities have been classed as not human, 'sub-human' or at least less than fully human. Indeed today some so-called 'human' rights are routinely denied to groups such as children (the right to vote), prisoners (the right to freedom of movement) and illegal immigrants (the right to equal access to the law), among others. Does denying them 'human rights' imply that somehow these people are less than fully human? It is important that, in thinking about human rights, we realise that the very idea of 'human' is contested, and has been so throughout history.

But the word 'human' is more than just a category, it also represents an ideal. There is a construction of the ideal human, embedded in Enlightenment ideas, which pervades Western culture, and which has affected the way in which 'human rights' have been understood. The characteristic Enlightenment ideal of the human is:

- Individual: the human is essentially an individualised rather than a collective ideal

- Young: vigorous youth is the ideal; once we become older our humanity diminishes

- Healthy and able-bodied: those with disabilities fall short of the human ideal

- White: the European Enlightenment went hand-in-hand with colonial expansion, and people of colour were regarded as less than human

- Male: the Enlightenment was concerned with 'the rights of man' and incorporated patriarchal assumptions. Women were less than 'fully human'

- Secular: the Enlightenment decentered religion and ideas of the sacred, in favour of scientific discovery and the power of human reason

- Characterised by mind/body dualism: the separation of mind from body, and the disembodiment of the human experience

- In a position of dominance over the natural world, which represent 'resources' for humans to use for their own ends

Although some aspects of this list would now be challenged, for example by feminist and post-colonial scholarship, disability advocates, radical ecologists, and so on, these attributes represent the legacy of 'human rights' as we have come to understand them, and they resonate with present Western cultural experiences; for example, racism is thriving in many western societies, there is a strong culture of idealised youth, patriarchy remains stubbornly strong, we are destroying the natural world in the name of greed and profit, and so on.

Such a construction of the ideal human, while unremarkable for the world of Enlightenment modernity, is quite foreign for people from different cultural backgrounds, most particularly Indigenous People, whose cultures embrace collectivism, the integration of the sacred and spiritual into all aspects of life, wisdom of elders, embodied expressions of 'humanity (e.g. through dance and song), profound respect for and connection to land, and so on (Turner 2010). It is 
important to bear this in mind whenever someone makes a statement about 'the human rights of Indigenous People'; what are the assumptions of the 'human' embedded in such a statement? Too often it is an unthinking, uncritical western understanding of the human who has rights; is not this simply imposing an alien view of 'humanity' on to a group with utterly different cultural understandings of what it means to be human and to realise one's human potential? In this way, conventional human rights discourse, however wellintentioned and 'enlightened', can readily perpetuate colonialism.

This suggests that, in the complex human rights debates about universalism and cultural relativism, it is not so much the 'rights' but the 'human' that we need to address. There is no single universal construction of an ideal humanity, and this must clearly inform how we think about 'human rights'. Such an emphasis on 'the human' as at the centre of 'human rights' implies a different starting point for the traditional debates about human rights, involving gender, race, class, universalism, colonialism, and so on. It means a turn to a discussion about what it means to achieve one's full 'humanity', and for this the traditional legal framework of human rights is quite deficient and has nothing much to say. Rather it suggests that the study and application of 'human rights' should start with the humanities, an area which has often been devalued in social work education in favour of the social sciences. Yet, as writers such as Martha Nussbaum have argued, if we are to have a healthy democracy, the humanities are not an option, but a necessity (Nussbaum 2010). It is through a rich interrogation of literature, art, poetry, music, history and philosophy that we can begin to think more carefully about the meaning(s) of humanity, and what it means to achieve one's true human potential. Because this will be constructed differently in different cultural contexts, it is important to include other cultural traditions of the humanities and not just the 'Western Canon' (Nussbaum herself draws extensively on Rabindranath Tagore, for example), and it is also important to approach this inquiry with an anthropological perspective, recognising and indeed welcoming cultural difference. In this way, we can start to see human rights as located within cultures, rather than the legal tradition of seeing human rights as located within jurisdictions.

This all suggests a very different starting point for social workers concerned with human rights. It requires us to address human rights from a study of the humanities, and also from social work's position of strength, namely an awareness of the importance of relationship (the 'social' with which we 'work'), and an awareness of not only the inevitability but also the desirability of cultural diversity. But to this we need to add an awareness of the limitations of Enlightenment Modernity as a paradigm for understanding the human, the problems that have been caused by the dominance of that world view, and creative alternatives that have been proposed as providing ways forward. These alternatives include postmodernism, post-colonial theory, critical whiteness, Indigenous world views, ecocentric philosophies, and others. Such an approach would enable social work to approach human rights in a very different way from the lawyers, rather than simply working alongside lawyers to help implement human rights treaties and instruments (important as this work undoubtedly is). Social work has always seen itself as helping people achieve their 'full humanity', and it is in this role that social workers have a unique and powerful contribution to make to achieving human rights, through transformative social work practice. How to do this, of course, is a complex challenge, outside the scope of the present paper, but this important new journal provides an ideal space for this to be effectively explored. The important point for present purposes is that social work has the potential not merely to fit in with conventional legal human rights discourse, but to shape and influence an alternative discourse based on the ideal of humanity and the importance of relationship.

\section{Some Further Challenges}

We live at a time when the anthropocentric world view is under significant challenge. No longer can we uncritically accept that human beings are the centre of creation or the ultimate stage of evolution, and that it is their destiny to 'have dominion over' other species and the earth. This view has caused major devastation to the earth, to other species, and is now also impacting on human 'civilisation' itself, as the inevitable limits to growth and exploitation become more evident. The separateness and exceptionalism of human beings in the natural world is being increasingly questioned, and there are significant calls for a more ecocentric world view, where it is our interdependence with the natural world that is paramount (Macy 2007; Shiva 2005). This view is, of course, common in Indigenous cultural traditions, where connection to the land, and to other life forms, is deeply and profoundly felt, and where a sense of the sacred pervades relationships between humans and the rest of the natural world. It is becoming increasingly clear that a similar ecocentric world view must be adopted if indeed some form of human civilisation is to survive the multiple ecological crises of the twenty-first century.

This perspective significantly challenges our concern for 'human' rights. Surely it will be necessary to expand the idea of 'rights' to emphasise our interconnection to the natural world, rather than continue with a discourse that implies human exceptionalism. Animal rights have become an area of increasing concern in recent decades. More recently, the governments of Bolivia and Ecuador have enshrined in legislation the idea of Pachamama, the 'rights of Mother Earth'. This extension of the idea of rights beyond the human, to include 
both animal rights and the rights of the earth itself, challenges our identification of 'rights' as 'human'. The implications of this for social work require much more exploration, as the idea of the 'social' is enlarged beyond the human species. There has been some initial theorising around social work and animal rights (Ryan 2011), and around social work and the environment (Jarvis 2013), but these areas of inquiry are in their infancy and have yet to impact mainstream social work.

To return briefly to the law, the ecocentric perspective poses a fundamental challenge to both jurisprudence and to legal practice. An important recent publication, drawing together a critique of the traditional legal paradigm and an ecocentric perspective is The Ecology of Law: Toward a Legal System in Tune with Nature and Community by Capra and Mattei (2015, see also Douzinas 2000, 2007). In this work the authors trace the development of both science and the law, and show that the latter has not kept up with the former in terms of the insights of ecology and holism. They challenge the narrow positivist modernity inherent in legal thinking and processes, and seek to reconstruct the idea of 'law' in a more ecological and holistic way, connected, as the title suggests, to both the natural world and to ecological ideas of community. If human rights based social workers are to remain relevant to the human condition, it is important that they take this critique seriously, and seek to articulate their practice within this newly emerging paradigm of what 'law' could become. The implications for social work, especially if it is to have a human rights basis, are both significant and exciting.

In the light of the above discussion, it might even be suggested that 'human rights' is becoming an outdated idea. Certainly there has been significant critique of traditional human rights and its perceived Western bias, and the coming ecological crisis raises the challenge to a whole new level; human rights may well reach its use-by date unless there is a rethinking of what human rights mean in a postmodern and ecologically interdependent world. Human rights represent a very powerful narrative of a just and fair world for humans (though not so far for the non-human), and they will continue to be important for social workers, and for others who are working for social justice. However if the idea of human rights is to retain its potency, it will need a reconfigured discourse, to take account of these challenges. Social workers are in a good strategic position to contribute to this reformulation, both theoretically and in practice.

\section{References}

Capra, F., \& Mattei, U. (2015). The ecology of law: towards a legal system in tune with nature and community. Oakland: BarrettKoehler.

Douzinas, C. (2000). The end of human rights: critical legal thought at the turn of the century. Oxford: Hart.

Douzinas, C. (2007). Human rights and empire: the political philosophy of cosmopolitanism. New York: Routledge-Cavendish.

Harvey, D. (2014). Seventeen contradictions and the end of capitalism. London: Profile Books.

Hunt, L. (2007). Inventing human rights: a history. New York: Norton.

Jarvis, D. (2013). Environmental justice and social work: a call to expand the social work profession to include environmental justice. Columbia Social Work Review, IV, 36-45.

Klein, N. (2014). This changes everything: capitalism vs. the climate. London: Penguin.

Macy, J. (2007). World as lover, world as self. Berkeley: Parallax Press.

Nussbaum, M. (2010). Not for profit: why democracy needs the humanities. Princeton NJ: Princeton University Press.

Ryan, T. (2011). Animals and social work: a moral introduction. London: Palgrave MacMillan.

Shiva, V. (2005). Earth democracy: justice, sustainability and peace. London: Zed Books.

Spretnak, C. (2011). Relational reality: new discoveries of interrelatedness that are shaping the modern world. Topsham: Green Horizon Books.

Tascón, S. (2015). Human rights film festivals: activism in context. London: Palgrave MacMillan.

Turner, M. (2010). Iwenha tyerrtye: what it means to be an aboriginal person. Alice Springs: IAD Press. 